\title{
MORPHOLOGICAL AND MOLECULAR CHARACTERIZATION OF SEVERAL NEOGASTROPOD SPECIES (MOLLUSCA: GASTROPODA) FROM COASTAL WATERS OF BANGLADESH WITH ONE NEW RECORD
}

\author{
KS Sultana ${ }^{1,2}$, PS Brishti1 1,3, S Ahmed², MB Billah ${ }^{3}$ and KA Habib1,4* \\ ${ }^{1}$ Aquatic Bioresource Research Lab., Department of Fisheries Biology and Genetics, Sher-e-Bangla \\ Agricultural University, Dhaka-1207, Bangladesh \\ 2Department of Zoology, Jagannath University, Dhaka-1100, Bangladesh \\ ${ }^{3}$ Department of Zoology, Jahangirnagar University, Savar, Dhaka-1342, Bangladesh \\ ${ }^{4}$ Department of Fisheries Biology and Genetics, Faculty of Fisheries, Aquaculture and Marine Science, \\ Sher-e-Bangla Agricultural University, Dhaka-1207, Bangladesh
}

\begin{abstract}
The present study reports the morphological and molecular characterization of marine neogastropods collected from the South-East to the South-West coasts of Bangladesh. A total of 21 species under 13 families were identified morphologically, of which 7 species were barcoded successfully using partial sequence of mitochondrial cytochrome oxidase subunit-I (COI) gene. The average nucleotide frequencies of these species were $\mathrm{G}$ (guanine) $=20.57 \%, \mathrm{C}$ (cytosine) $=18.44 \%, \mathrm{~A}$ (adenine) $=23.65 \%$, $\mathrm{T}$ (thymine) $=37.35 \%$ and the GC content was $39.01 \%$. The average Kimura two-parameter (K2P) distances of the $\mathrm{CO}$ barcode sequences within species, genera, and families were $20.7 \%, 22.0 \%$, and $22.0 \%$, respectively. The average inter-species genetic divergence was calculated as $21.0 \%$. In addition, the COI barcode sequence of Nassarius stolatus was identified and submitted to the GenBank for the first time. The study also reports the new record of a species, Indothais rufotincta Tan \& Sigurdsson, 1996 from Bangladesh. This finding greatly extends the distributional range of this species from the West coast to the East coast of the Bay of Bengal.
\end{abstract}

Key words: Bangladesh, DNA barcoding, Genetic distance, Indothais rufotincta, Neogastropoda, Phylogeny

\section{Introduction}

Gastropoda, the most diversified class of Mollusca, with more than 100,000 extant species, constitutes 80\% of all molluscs (Haszprunar and Wanninger 2012), of which marine gastropods comprise approximately 60,000 shelled gastropods and 13,000 sea slugs (Geiger 2006). According to Siddiqui et al. (2007), 318 species of gastropods are recorded from Bangladesh territory, of which 282 marine, 16 freshwater and 20 terrestrial. Wahab et al. (2012) mentioned that 26 freshwater and 336 marine gastropods are found in Bangladesh. Hossain et al. (2014) reported 121 species of marine gastropods belonging to 27 families from South-eastern coastal region of Bangladesh.

Though gastropods are a well-studied group, many aspects of the taxonomy, systematics, and evolutionary relationships of some gastropods are yet to be resolved (Borges et al. 2016). Presently, gastropods are mainly identified on the traditional morphological characteristics. However, accurate identification of molluscan species is sometimes difficult due to their extensive diversity in morphological features. Further,

*Author for correspondence: ahsan.sau@gmail.com; habibka@sau.edu.bd 
most of the gastropods have different morphological features at their different growth stages. Phenotypic plasticity results in changes in shell morphology, leading to the development of synonyms and homonyms of species, which necessitates molecular characterization (Altaf et al. 2017). As a molecular tool, DNA barcoding is recognized as a quick and reliable method for species identification (Herbert et al. 2003) and has been widely used, especially for disclosing cryptic species (Johnson et al. 2008, Weigt et al. 2012).

Neogastropoda (Mollusca: Gastropoda) is a highly diversified predatory and scavenging group of marine snails that constitutes almost one-quarter of the diversity of marine molluscs. Over 12,000 species of neogastropods are classified under 40 families that play a key role in the marine benthic ecosystem (Fedosov et al. 2015). Earlier on, Siddiqui et al. (2007) reported 282 species of marine gastropods, of which 125 species were neogastropods that belonged to 50 genera and 19 families. Hossain et al. (2014), on the other hand, reported a total of 46 neogastropod species under 11 families from Kutubdia, Maheskhali and Sonadia Islands along the South-eastern coastline of Bangladesh. In the present study, morphological identification and molecular characterization of the collected neogastropods from SE and SW coastal waters of Bangladesh were carried out to differentiate one species from the other using genetic distance and phylogenetic assessment tools.

\section{Materials and Methods}

\section{Study area and sample collections}

Samples were collected by direct hand picking from the intertidal or subtidal zones of Sonadia Island $\left(21^{\circ} 28^{\prime} 38.8^{\prime \prime} \mathrm{N}\right.$; 91 $\left.91^{\circ} 55^{\prime} 23.1^{\prime \prime} \mathrm{E}\right)$, Dublar Char $\left(21^{\circ} 45^{\prime} 03.8^{\prime \prime} \mathrm{N}\right.$; 89 $\left.33^{\circ} 15.8^{\prime \prime} \mathrm{E}\right)$, Cox's Bazar sea beach $\left(21^{\circ} 27^{\prime} 48.6^{\prime \prime} \mathrm{N} ; 9^{\circ} 56^{\prime} 47.1^{\prime \prime E}\right)$ and Saint Martin's Island $\left(20^{\circ} 36^{\prime} 34.7^{\prime \prime} \mathrm{N} ; 9^{\circ} 19^{\prime} 40.0^{\prime \prime} \mathrm{E}\right)$ located in the southeast coast of Bangladesh. Diversity of molluscan fauna in these areas is higher than the other coastal sites of the country. These areas possess sandy, sandy-muddy to muddy beaches, mangroves, seagrass beds and dunes, which make these places a unique habitat for marine molluscan fauna (Arefin et al. 2017). Samples were also collected from Dublar Char of the Sundarbans mangrove forest area in the South-West coast of the country. The present study was conducted from June 2017 to December 2019. After collecting, the samples were initially preserved in ice bucket with crushed ice until they were transferred to $-18^{\circ} \mathrm{C}$ in Aquatic Bioresource Research Laboratory, Department of Fisheries Biology and Genetics, Sher-e-Bangla Agricultural University, Bangladesh. All the collected samples were tagged and photographed by a digital camera. Tissue samples were collected from the specimens that had muscles inside the shell and were preserved in $99 \%$ ethanol for molecular study.

\section{Morphological identification}

Specimens were identified mostly on the basis of shell characteristics following Rao et al. (1992), Tan and Sigurdsson (1996), Poutiers (1998), Ramakrishna et al. (2007) and Siddiqui et al. (2007). All observations were recorded in data sheets for final analyses.

\section{Genomic DNA extraction, PCR amplification and DNA sequencing}

Genomic DNA was extracted from the collected tissues using a TIANamp Marine Animals DNA Kit (TIANGEN, China) following the protocol provided inside the kit box. The concentration of genomic DNA was then measured by Qubit 3.0 fluorometer (Germany). The polymerases chain reaction (PCR) was performed 
in a $25 \mu$ reaction mixture in $0.2 \mathrm{ml}$ reaction tubes in the thermal cycler $(2720$ Thermal Cycler, Applied Biosystems, UK). The barcode region of mtDNA COI gene was amplified by using universal primers commonly known as 'Folmer primers' (LCO1490 5'-GGT CAA CAA ATC ATA AAG ATA TTG G-3' and HCO2198 5'-TAA ACT TCA GGG TGA CCA AAA ATC A-3') designed by Folmer et al. (1994). The thermal cycling conditions included an initial denaturation temperature of $95^{\circ} \mathrm{C}$ for 5 minutes, followed by 35 cycles of $95^{\circ} \mathrm{C}$ for $1 \mathrm{~min}$ for denaturation, $49^{\circ} \mathrm{C}$ for $1 \mathrm{~min}$ for annealing, $72^{\circ} \mathrm{C}$ for $1: 30 \mathrm{~min}$ for extension and $72^{\circ} \mathrm{C}$ for 5 min for final extension. For the species that were not amplified by the universal $\mathrm{CO}$ primers, another primer set (COXAF 5'-CWA ATC AYA AAG ATA TTG GGA-3' and COXAR 5'-AAT ATA WAC TTC WGG GTG ACC-3') designed by Colgan et al. (2001) were used. In this case, the thermal cycling condition included an initial denaturation temperature of $94^{\circ} \mathrm{C}$ for 3 min followed by 35 cycles of $94^{\circ} \mathrm{C}$ for $30 \mathrm{~s}, 48^{\circ} \mathrm{C}$ for $1 \mathrm{~min}$ and $72^{\circ} \mathrm{C}$ for $1 \mathrm{~min}$ with final extension of $72^{\circ} \mathrm{C}$ for $10 \mathrm{~min}$. PCR products were visualized on $1 \%$ agarose gel (Invitrogen, USA) stained with ethidium bromide in gel documentation chamber (Syngene InGenius ${ }^{3}$ USA). The flow UV-ray was kept on to watch the band in the connected computer by using GeneSys software (USA). PCR samples with a single and clear visible band were purified with the PCR purification kit (TIANGEN- Universal DNA Purification Kit, China) for sequencing. The extracted DNAs were sequenced from a local commercial sequencer (Biotech Concern). The software Geneious (version 9.0.5) was used for editing nucleic acid sequences. The obtained consensus sequences were then edited based on the chromatogram peak clarities with the help of Chromas Lite. BLAST (Basic Local Alignment Search Tool) was used to check sequence identity between the obtained sequences and database of sequences from the GenBank at National Center for Biotechnology Information (NCBI) and BOLD (Barcode of Life Data) database. This helped to identify sequence similarity across gene sequence data of the NCBI.

\section{DNA sequence analyses and molecular characterization}

Sequence data were assembled and edited using the MEGA-7 software (Kumar et al. 2016) and subsequently submitted to BOLD and GenBank. Specimens and collected data, along with sequences and trace files, were provided to the project 'MSK DNA Barcoding of Marine Molluscs, Bangladesh in BOLD. Sequences were aligned using ClustalW in MEGA 7 software, and different parameters such as the sequence length, polymorphic loci and parsimony informative sites were calculated. Sequence composition analysis was performed in BOLD. Sequence divergence was calculated using the Kimura two-parameter (K2P) model in MEGA 7 software (Kimura 1980), which was also used for constructing the phylogeny by Neighbor-Joining (NJ) method (Saitou and Nei 1987) with 10000 bootstrap replications. The COI sequences of conspecifics reported to GenBank from other countries were used for evaluating genetic distance and phylogenetic assessment. The barcode sequences of the present study made a single clade in the phylogeny with low (usually <2\%) or no genetic distance (Hebert et al. 2003) with the conspecifics of other localities which will validate the accuracy of the species identification.

\section{Results}

\section{Morphological identification}

A total of 21 species of neogastropods were identified morpho-meristically (Figs. 1-3), which belonged to 17 genera and 13 families viz. Muricidae, Clavatulidae, Volutidae, Babyloniidae, Melongenidae, Nassariidae, Conidae, Olividae, Ancillariidae, Harpidae, Pisaniidae, Columbellidae and Architectonicidae. One species 
Indothais rufotincta (Fig. 3. 22A and B), was identified as a new record from Bangladesh, whose brief systematics is shown below:

$\begin{array}{lll}\text { Family } & : & \text { Muricidae Rafinesque } 1815 \\ \text { Sub-family } & : & \text { Rapaninae Gray } 1853 \\ \text { Genus } & : & \text { Indothais Claremont et al. } 2013 \\ \text { Species } & : & \text { I. rufotincta Tan and Sigurdsson } 1996 \\ \text { Indothais rufotincta } & : & \text { Tan and Sigurdsson (1996), pp. 86-93, PI. 2, Figs. a\&b; PI 3, Figs. a-f. } \\ \text { Cuma javanica } & : & \text { Oostingh (1923); 113, Fig. } 13 \text { (not Purpura javanica Philippi 1848) } \\ \text { Synonymy } & : & \text { Thais rufotincta Tan and Sigurdsson 1996, original combination } \\ & & \text { Thaisella rufotincta (Tan and Sigurdsson 1996). } \\ \text { Type locality } & : & \text { Java Island, Indonesia }\end{array}$

Material examined: One shell; M1711SM-25, 20 $0^{\circ} 36^{\prime} 34.7^{\prime \prime} \mathrm{N}$ and $92^{\circ} 19^{\prime} 40.0^{\prime \prime} \mathrm{E}$, St. Martin's Island, was collected by Amit Kumer Neogi in November, 2017 (Fig. 4).

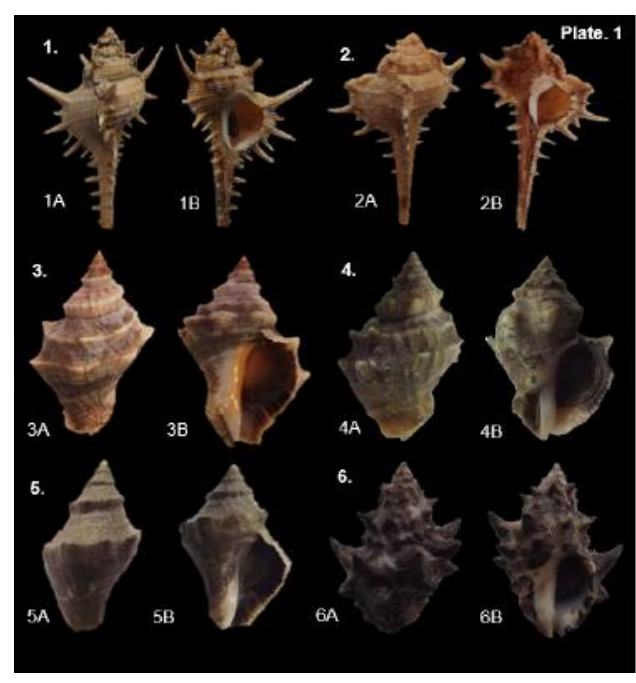

Fig. 1: Photographs of the species: 1. Murex ternispina; 2. Murex trapa; 3, 4, 5. Indothais lacera; 6. Mancinella armigera. A and B of each number denote dorsal and ventral views of the species, respectively.

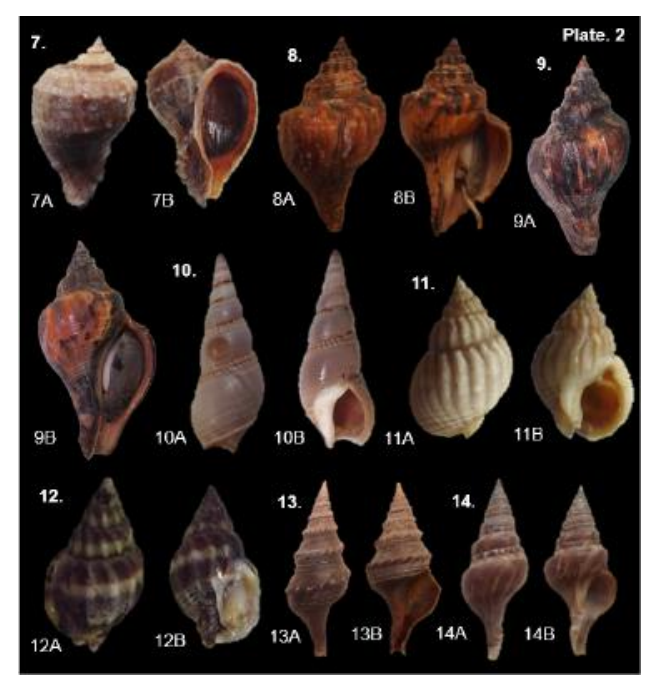

Fig. 2: Photographs of the species: 7. Rapana rapiformis; 8. 9. Volegalea cochlidium; 10. Bullia vittata; 11. Nassarius stolatus; 12. Nassarius nodiferus; 13. Turricula javana; 14. Turricula tornata. 

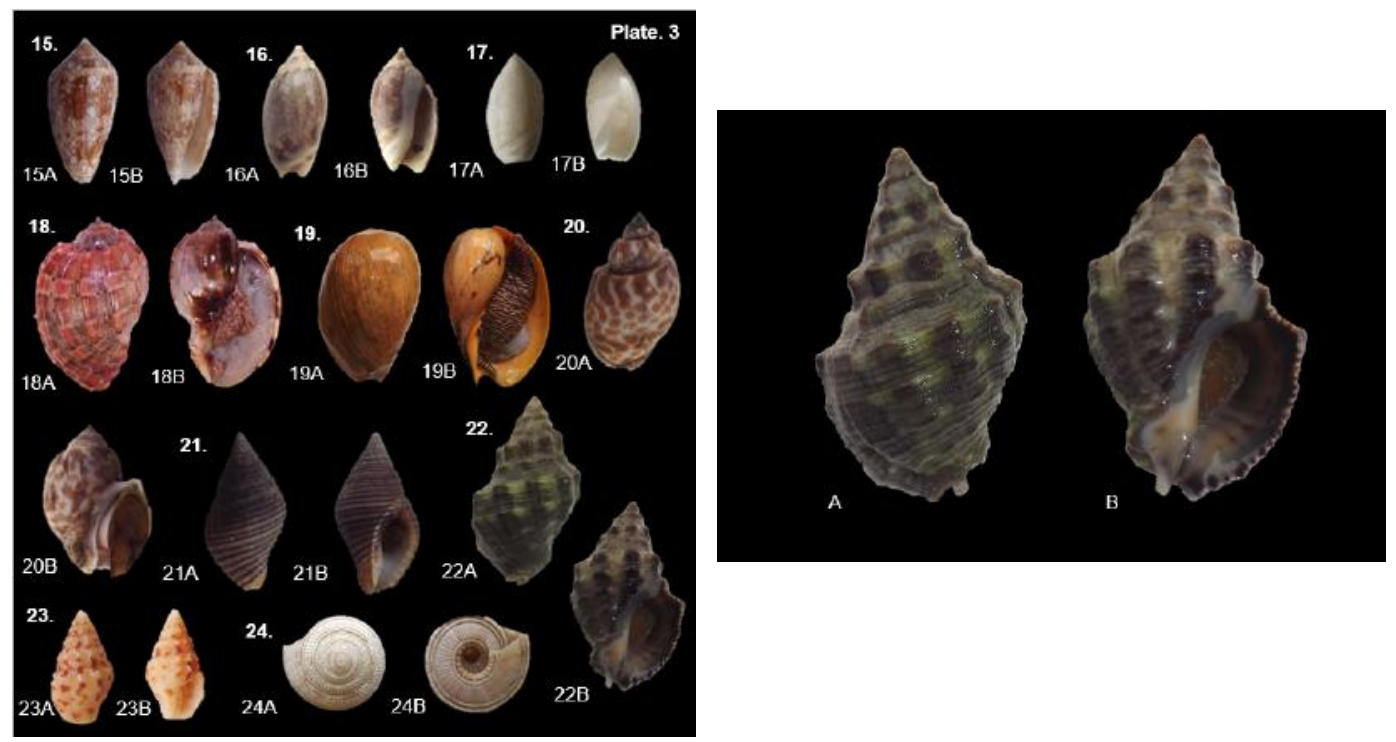

Fig. 3: Photographs of the species: 15. Conus textile; 16. Agaronia gibbosa, 17. Ancilla ampla, 18. Harpa davidis, 19. Melo melo, 20. Babylonia spirata, 21. Pollia undosa, 22. Indothais rufotincta, 23. Anachis miser, 24. Architectonica laevigata.

\section{Diagnosis}

The morphometric measurements of the snails were shell length $(S L)=2.9 \mathrm{~cm}$, shell width $(S W)=1.8 \mathrm{~cm}$, aperture length $(A L)=1.8 \mathrm{~cm}$, and aperture width $(A W)=1.2 \mathrm{~cm}$. Shell medium-sized, thick, solid, angulated; almost bi-conical in outline; body with a moderately tall, conical spire, protoconch distinct; body whorl larger than spire; with a distinct angulation at the shoulder. Last whorl bears four rows of primary spiral cords, shoulder row comprises prominent compressed tubercles, second row has comparatively smaller tubercles, the third and fourth row tubercles are obsolete. Tubercles are tinged reddish-brown, a prominent feature of the shell. Sutural ramp is narrow, somewhat concave, consists of 3-5 narrow cords. The nodules of the shell surface are more or less axially aligned; hence they form low varices. Each primary spiral cord bears brown $\&$ white dashes; here brown regions often represent the varices and the white regions represent the space between the varices. Aperture auriform with smooth columellar fold. Margin of outer lip crenate, inner edge of outer lip bears 4-8 ridge-like thin lirae. Inner side of outer lip of the shell is bluish-white to creamy with a thickened edge, but stained brown in colour in those places that are still in actively growing phase. The columella is stained brown at the parietal region but the rest is creamy to bluish-light brown. Siphonal canal is elevated along with distinct siphonal fasciole. 


\section{Distribution and habitat}

Although common in East coast of India, Malayan Archipelago, South China Sea, Western Central Pacific, Thailand, Indonesia, Singapore, Malaysia, Guam and Vietnam (Gumert and Malaivijitnond 2012, Islami et al. 2019, Global Biodiversity Information Facility (GBIF) 2019), the available distribution records show that Indothais rufotincta was not previously reported from Bangladesh. Occurrence of this species in the Saint Martin's Island of the country currently revealed its range extension to the SE and SW coastal waters of the Bay of Bengal (Fig. 5).

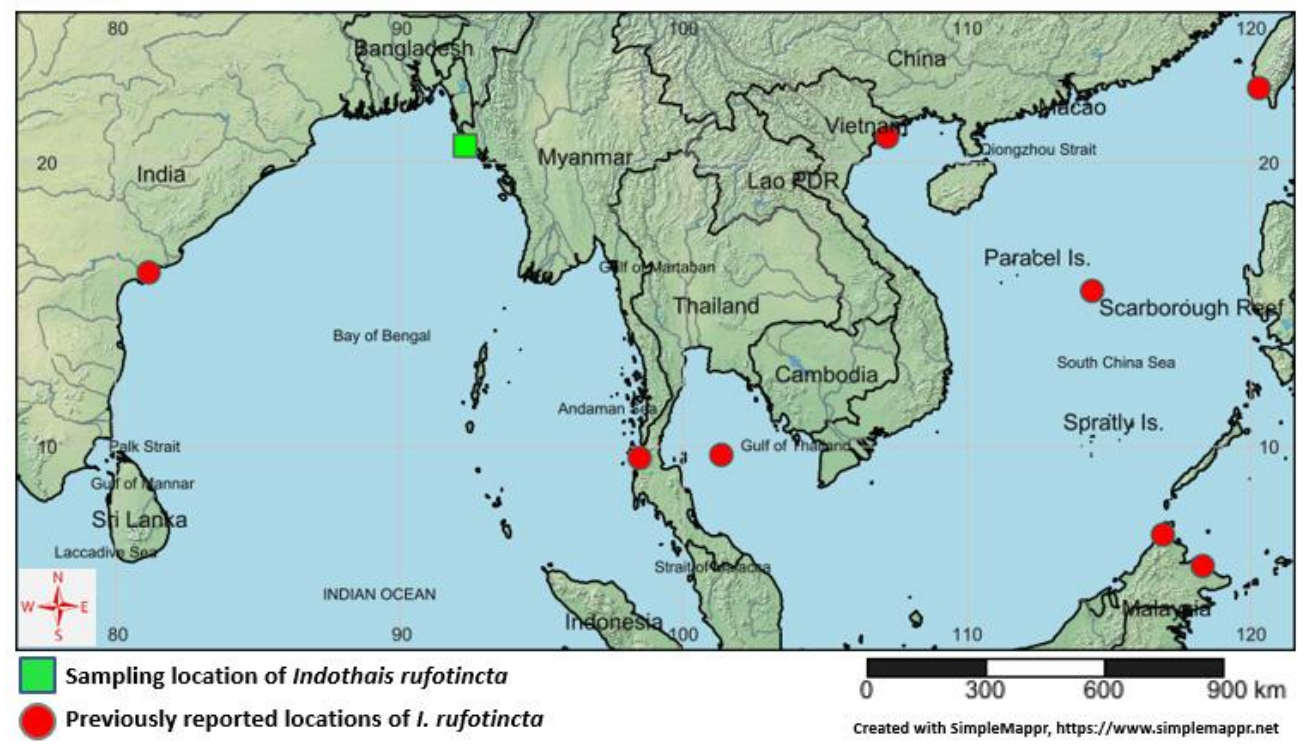

Fig. 5: Map showing sampling location and previously reported sites of Indothais rufotincta.

\section{Molecular characterization}

Among morphologically identified 21 species, 7 species were successfully barcoded which were Rapana rapiformis, Indothais lacera, Turricula javana, Volegalea cochlidium, Nassarius stolatus, Babylonia spirata and Melo melo belonging to 6 families. No insertions/deletions or codon stops were found in COI amplicons, supporting the view that all of the amplified sequences constitute functional mitochondrial $\mathrm{COI}$ sequences. The average sequence length was about 603 base pairs (bp) ranging from 550 to $605 \mathrm{bp}$. Overall mean nucleotide frequencies were as follows: $\mathrm{G}=20.57 \%, \mathrm{C}=18.44 \%, \mathrm{~A}=23.65 \%, \mathrm{~T}=37.35 \%$ and the $\mathrm{GC}$ content was $39.01 \%$. The nucleotide frequencies for each of the individual species are shown in Fig. 6 . The GC contents at the first, second and third codon positions for 7 sole neogastropod species were $52.89 \%$, $42.48 \%$ and $21.56 \%$, respectively. Distribution graphs for the GC composition by codon position are shown in Fig. 7. Nucleotide pair frequency analysis of the entire dataset revealed that 385 of 605 sites were conserved, 220 of 605 sites were variable, 196 of 605 sites were parsimony informative and 24 sites were singleton. 


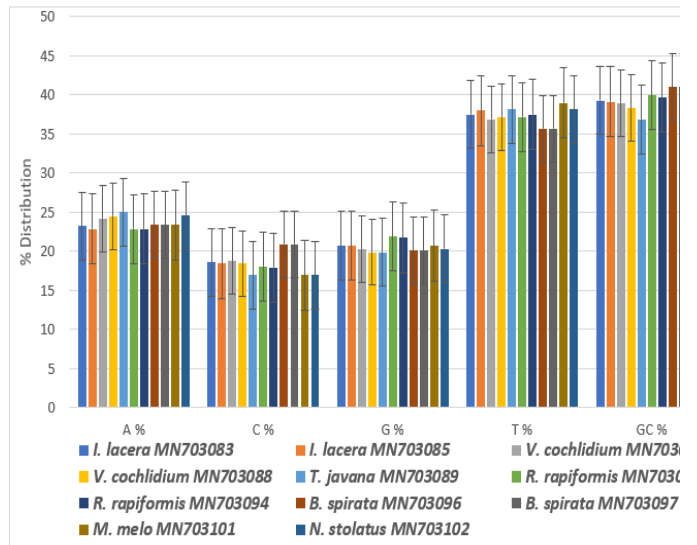

Fig. 6: Composition of the nucleotides in the sequenced $\mathrm{COI}$ region of 7 neogastropod species from Bangladesh.

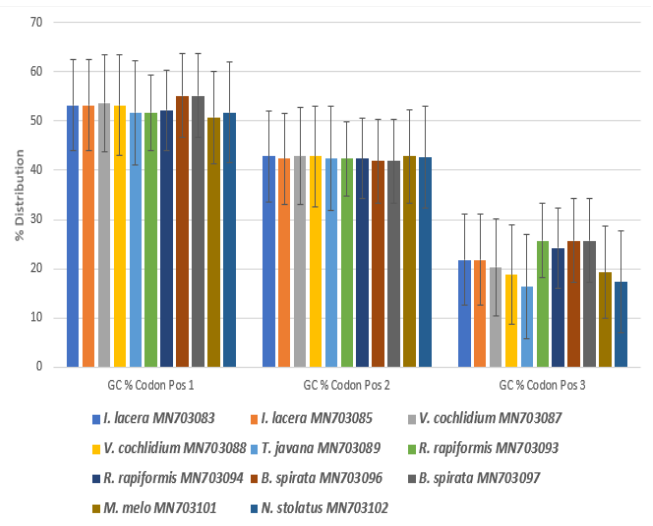

Fig. 7: GC content in different codon positions in the COI barcode region of neogastropod species under study.

K2P model was used to calculate the genetic distances within and between species for the barcoded species used in this study. The K2P distances of the COI sequence within species ranged from 0 to $1 \%$, with an average distance of $0.58 \%$. The maximum distance of $1 \%$ was found within the individuals of Volegalea cochlidium and the distances for remaining species were less than $1 \%$. The genetic distances between species was $0.7 \%$ to $25 \%$, with an average of $20.7 \%$, between genera was $19 \%$ to $25 \%$, with an average of $22 \%$; and the genetic distances between families was found $19 \%$ to $25 \%$, with an average of $22 \%$. Estimates of evolutionary divergence over sequence pairs between species of neogastropods under study has been shown in Table 1. The data showed that the maximum K2P distance was same (i.e. 25\%) at different taxonomic levels under the order Neogastropoda in the present study which indicates that genetic diversity is low among the species. In agreement with this study, Cunha et al. (2009) also obtained low genetic diversity among the species of neogastropods.

In the phylogeny (Fig. 8), species within genera invariably clustered, and generally so did genera within families with very high bootstrap values $70-100 \%$. We found the highest number of species from the family Muricidae. They clustered separately in the NJ tree. The lowest genetic divergence was calculated as $19 \%$ between the family Clavatulidae and Volutidae and the highest genetic divergence was found as $25 \%$ between the family Muricidae and Melongenidae. In the species level, the highest genetic divergence was found between Turricula javana, and Melo melo, and the highest genetic divergence was found between Rapana rapiformis and Volegalea cochlidium. The average inter-species genetic divergence was calculated as $21 \%( \pm 1 \%)$. 


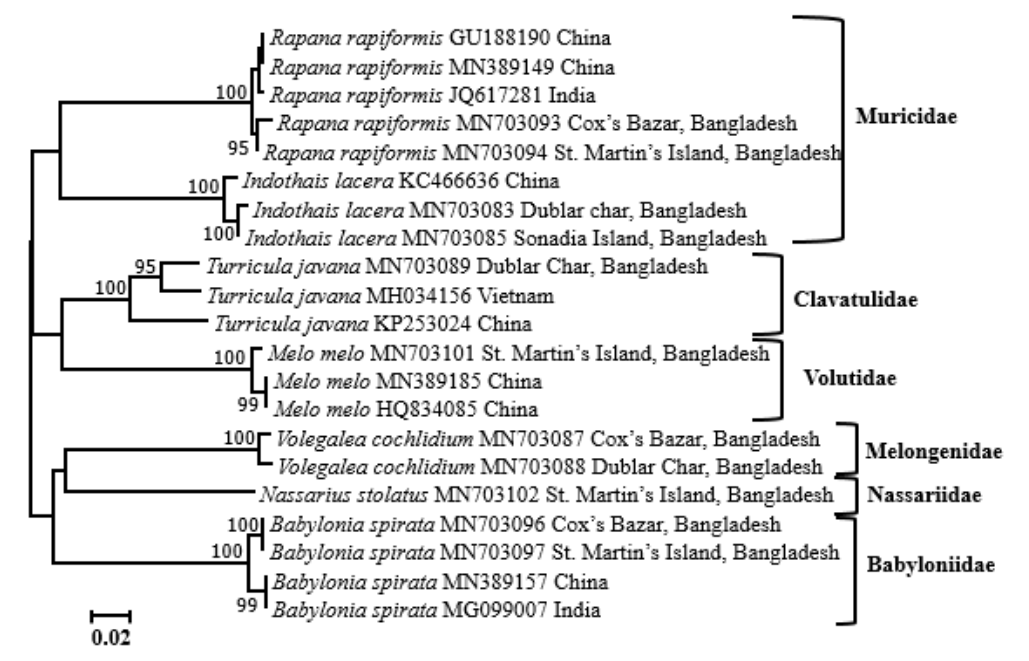

Fig. 8: Neighbor-joining tree of the 7 neogastropod species constructed using the K2P model for COI barcode sequences. Bootstrap support of $>90 \%$ are shown above branches. Scale bar indicates the number of nucleotide substitutions per site.

\section{DNA barcoding of Indothais rufotincta}

For DNA barcoding of Indothais rufotincta a partial sequence of mitochondrial COI gene was amplified and sequenced. Unfortunately, we were unable to get clear full length (approximately $600 \mathrm{bp}$ ) sequence after sequencing. The clear nucleotide sequence of about $200 \mathrm{bp}$ from $5^{\prime}$ region was possible to detect. We have tried couple of times to get long sequence but got same result. However, the BLAST search result with obtained sequence (200 bp) showed 100\% similarity with a sequence of GenBank submitted from Malaysia (GenBank accession no: MF520763). The identified COI sequence of present study was submitted to the BOLD System in the project 'MSK DNA barcoding of Marine Molluscs, Bangladesh' under the BOLD identification number MSK055-20. The conspecific sequences of COI barcode gene of Indothais rufotincta submitted from Malaysia were retrieved from the GenBank and used in the phylogenetic analysis with the sequence of Bangladesh (Fig. 9). The species Indothais javanica was used as an out-group in the phylogeny. Genetic distance between the sequence of Bangladesh and three sequences of Malaysia ranged from 0 to $6 \%$. The sum of branch length of the phylogenetic tree was 0.025 .

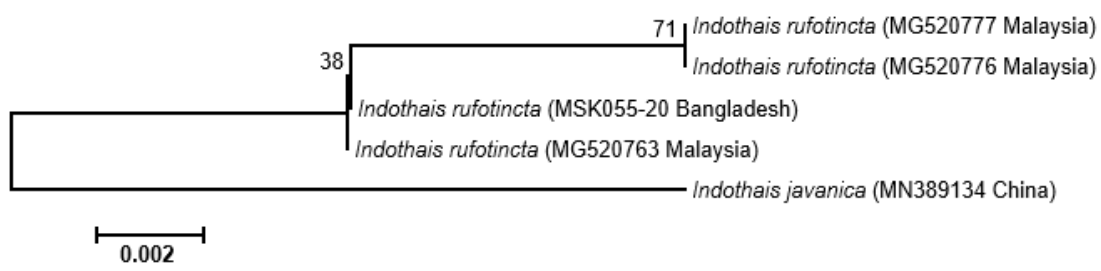

Fig. 9: Neighbor-joining tree constructed using the K2P model for $\mathrm{COI}$ gene sequences of Indothais rufotincta of present study and conspecific sequences retrieved from GenBank. Bootstrap supports are shown above branches. GenBank accession number and country of each sequence are provided within parenthesis. Indothais javanica was used as an out-group in the tree. 


\section{Discussion}

The specimens of molluscs are sometimes difficult to discriminate among species due to the complex larval stages and phenotypic plasticity in shell morphology and cryptic characteristics (Johnson et al. 2008, Marko and Moran 2009, Weigand et al. 2011, Zou et al. 2011). Molecular marker, particularly DNA barcode, is considered as better choice for species differentiation due to non-recombinant and environment independent nature (Blaxter 2004, Kumar et al. 2015). Barcoding has clearly discriminated molluscan species from around the world including China, South Africa, India, Northwestern Pacific and USA (Perez et al. 2014, Kumar et al. 2015, Bank and Greenfield 2015, Sun et al. 2016, Ran et al. 2020).

All of the seven barcoded species in the present study were differentiable based on the individual $\mathrm{COI}$ barcodes. The average inter-species genetic divergence was calculated as $21 \%( \pm 1 \%)$. Hence, the diversity of these $\mathrm{COI}$ barcode sequences was reasonably sufficient to discriminate the species within a genus which strongly validated the efficiency of COI barcodes for identifying neogastropod species. Further, the COI barcode sequence of Nassarius stolatus was identified and submitted to GenBank for the first time.

Apart from 7 species, few more species had muscles inside their shells but we failed to get clear nucleotide sequences. Another problem that we faced in DNA barcoding of neogastropods was non-amplification of $\mathrm{COI}$ barcode region for some species in PCR with 'Folmer primers (HCO2198 and LCO1490). In this case, another primer set suggested by Colgan et al. (2001) was used but it showed poor performance. Therefore, design of new primers for $\mathrm{COI}$ barcode region specific for neogastropods may improve the efficiency of the DNA barcoding. Among the collected neogastropods, the species Indothais rufotincta was recorded for the first time in the coastal waters of Bangladesh. Oostingh (1923) first recorded Indothais rufotincta but he mistakenly identified it as Indothais javanica (Philippi 1848). The Indothais javanica is found in Southeast and Northeast Asia, and it differs from Indothais rufotincta in having 10-12 low, ridge-like tubercles on the carina and siphonal canal that is dorsally upturned (Tan and Sigurdsson 1996, Palomares and Pauly 2020). The ratio of both SL/SW and SL/AL was found as 1.6 in the present study. Tan and Sigurdsson (1996) calculated these measurements as 1.58 (2.35/1.48); and 1.52 (2.35/1.57), respectively.

Diversity of gastropod molluscs in Bangladesh is being decreased day by day due to their vast exploitation such as making poultry and fish feed, lime production, shell crafts manufacturing and paint making. Rapid growth of tourism in Cox's Bazar, Saint Martin's Island, Sonadia Island and Dubla Island is another factor that is threatening for the ecosystem of the molluscs. Such indiscriminate exploitations along with habitat loss are causing negative impact on the mollusc diversity in the county, where an urgent initiative is needed for conservation of this group of fauna. The local conservation status using the IUCN Red List Criteria (IUCN 2003, IUCN 2012) of molluscs in Bangladesh has not been assessed yet. However, the global IUCN Red List of Threatened Species (IUCN 2020) and SeaLifeBase (Palomares and Pauly 2020) indicated the status of all of the neogastropod species as 'not evaluated (NE)' except Conus textile, which was found as "Least Concern (LC)". It means, Conus textile has been evaluated against the criteria and does not qualify for Critically Endangered, Endangered, Vulnerable or Near Threatened species. But, it does not imply that this species is of no conservation concern. On the other hand, the category of NE denotes that these species have not yet been studied for any risk to be quantified and published (IUCN 2012). The present work has generated DNA barcodes for seven species of neogastropods distributed in the SE and SW coastal waters of Bangladesh. These barcodes will be helpful in identification, assessment and in preparing conservation strategies for the marine snails. 
Table 1. Estimates of evolutionary divergence over $\mathrm{COI}$ sequence pairs between species of neogastropods under study

\begin{tabular}{|c|c|c|c|c|c|c|c|c|c|c|c|c|c|c|c|}
\hline Species & Locations & $\begin{array}{l}\text { Seq. } \\
\text { No. }\end{array}$ & $\mathrm{NCBI}$ & Voucher No. & HAP & 1 & 2 & 3 & 4 & 5 & 6 & 7 & 8 & 9 & 10 \\
\hline \multirow[t]{2}{*}{ Rapanar rapiformis } & CXB & 1 & MN703093 & M1902DoF-07 & A & - & & & & & & & & & \\
\hline & SMI & 2 & MN703094 & M1903SM-14 & B & 0.007 & - & & & & & & & & \\
\hline \multirow[t]{2}{*}{ Indothais lacera } & $\mathrm{DBI}$ & 3 & MN703083 & M1901DC-01 & C & 0.215 & 0.207 & - & & & & & & & \\
\hline & $\mathrm{SNI}$ & 4 & MN703085 & M1904SD-19 & D & 0.210 & 0.203 & 0.003 & - & & & & & & \\
\hline Turricula javana & $\mathrm{DBI}$ & 5 & MN703089 & M1901SD-19 & $\mathrm{E}$ & 0.207 & 0.204 & 0.224 & 0.219 & - & & & & & \\
\hline Melo melo & SMI & 6 & MN703101 & M1711SM-01 & $\mathrm{F}$ & 0.226 & 0.219 & 0.224 & 0.219 & 0.187 & - & & & & \\
\hline \multirow[t]{2}{*}{ Babylonia spirata } & CXB & 7 & MN703096 & M1902DoF-15 & G & 0.244 & 0.238 & 0.233 & 0.228 & 0.196 & 0.235 & - & & & \\
\hline & SMI & 8 & MN703097 & M1903SM-05 & - & 0.244 & 0.238 & 0.233 & 0.228 & 0.196 & 0.235 & 0.000 & - & & \\
\hline \multirow[t]{2}{*}{ Volegalea cochlidium } & CXB & 9 & MN703087 & M1901DC-05 & I & 0.247 & 0.244 & 0.250 & 0.250 & 0.191 & 0.241 & 0.213 & 0.213 & - & \\
\hline & $\mathrm{DBI}$ & 10 & MN703088 & M1901DC-27 & $\mathrm{J}$ & 0.257 & 0.249 & 0.236 & 0.236 & 0.200 & 0.241 & 0.218 & 0.218 & 0.010 & - \\
\hline Nassariuss stolatus & SMI & 11 & MN703102 & M1903SM-15 & $\mathrm{K}$ & 0.228 & 0.218 & 0.216 & 0.216 & 0.187 & 0.248 & 0.216 & 0.216 & 0.205 & 0.202 \\
\hline
\end{tabular}

CXB: Cox's Bazar; SMI: Saint Martin's Island; DBI: Dublar Island; SNI: Sonadia Island; HAP: Haplotype; NCBI: NCBI accession number. 


\section{Conclusion}

The outcome of the present study reveals a significant contribution to DNA barcode reference sequences of marine neogastropods of Bangladesh. In addition, the species Indothais rufotincta Tan \& Sigurdsson, 1996 has been recorded for the first time in Bangladesh which greatly extends its distributional range from the West coast to the East coast of the Bay of Bengal. Studies on the biology and taxonomy of gastropod species of Bangladesh are needed with the assistance of DNA barcoding in order to provide vital information for assisting conservation efforts.

\section{Acknowledgements}

This work was supported by the Grant of Advanced Research in Education (GARE) of the Ministry of Education, People's Republic of Bangladesh (Grant ID: 2018734). We acknowledge Amit Kumer Neogi and Md. Jayedul Islam for assisting in sample collection. We are grateful to the anonymous reviewers for their comments and suggestions to improve the manuscript.

\section{Contribution}

The authors KS Sultana and PS Brishti contributed equally to this work and will be considered as joint first authors.

\section{References}

Altaf J, Qureshi NA and Siddiqui MJI (2017). Genetic diversity analysis of snail species (Mollusca: Gastropoda) using molecular marker technology. Journal of Biodiversity and Environmental Sciences, 10(1): 26-35.

Arefin MS, Hossain MK and Hossain MA (2017). Plant diversity of Sonadia Island - An ecologically critical area of SouthEast Bangladesh. Bangladesh Journal of Plant Taxonomy, 24(1): 107-116.

Bank HVD and Greenfield R (2015). A pioneer survey and DNA barcoding of some commonly found gastropod molluscs on Robben Island. Zoo Keys, 481: 15-23.

Blaxter ML (2004). The promise of a DNA taxonomy. Philosophical Transactions of the Royal Society B: Biological Sciences, 359(1444): 669-679.

Borges LMS, Hollatz C, Lobo J, Cunha AM, Vilela AP, Calado G, Coelho R, Costa AC, Ferreira MSG, Costa MH and Costa FO (2016). With a little help from DNA barcoding: investigating the diversity of Gastropoda from the Portuguese coast. Scientific Reports, 6(1): 20226.

Claremont M, Vermeij GJ, Williams ST and Reid DG (2013). Global phylogeny and new classification of the Rapaninae (Gastropoda: Muricidae), dominant molluscan predators on tropical rocky seashores. Molecular Phylogenetics and Evolution, 66(1): 91-102.

Colgan DJ, Hutchings PA and Brown S (2001). Phylogenetic relationships within the Terebellomorpha. Journal of the Marine Biological Association of the United Kingdom, 81(5): 765-773.

Cunha RL, Grande C and Zardoya R (2009). Neogastropod phylogenetic relationships based on entire mitochondrial genomes. BMC Evolutionary Biology, 9(1): 210.

Fedosov A, Puillandre N, Kantor $Y$ and Bouchet $P$ (2015). Phylogeny and systematics of mitriform gastropods (Mollusca: Gastropoda: Neogastropoda). Zoological Journal of the Linnean Society, 175(2): 336-359.

Folmer O, Black M, Hoeh W, Lutz R and Vrijenhoek R (1994). DNA primers for amplification of mitochondrial cytochrome C oxidase subunit I from diverse metazoan invertebrates. Molecular Marine Biology and Biotech., 3(5): 294-299. 
GBIF (Global Biodiversity Information Facility) 2019. Indothais rufotincta (Tan KS and Sigurdsson 1996) in GBIF Backbone Taxonomy. Checklist dataset available at https://doi.org/10.15468/39omei.

Geiger DL (2006). Marine Gastropoda. In: Sturm CF, Pearce TA and Valdés (Eds.). The mollusks: a guide to their study, collection, and preservation. American Malacological Society, Pittsburgh, PA, USA, pp. 295.

Gray JE (1853). On the division of Ctenobranchous Gasteropodous Mollusca into larger groups and families. Annals and Magazine of Natural History: Ser. 2, 11(62): 124-133.

Gumert MD and Malaivijitnond S (2012). Marine prey processed with stone tools by burmese long-tailed macaques (Macaca fascicularis aurea) in intertidal habitats. American Journal of Physical Anthropology, 149(3): 447-457.

Haszprunar G and Wanninger A (2012). Molluscs. Current Biology, 22(13): 510-514.

Hebert PDN, Ratnasingham S and deWaard JR (2003). Barcoding animal life: cytochrome c oxidase subunit 1 divergences among closely related species. Proceedings of the Royal Society B: Biological Sciences, 270 (Suppl.1): S96-S99.

Hossain MS, Sharifuzzaman SM, Chowdhury SR, Chowdhury MSN, Sarkar S, Islam MR and Talukder A (2014). Sea shells of Bangladesh: Marine Gastropod and Bivalve Molluscs Biodiversity, pp.1-44.

Islami MM, Sari AP, Tala DJ and Baszary CDU (2019). Imposex study on Thais aculeata (Gastropoda: Muricidae) in Ambon Bay, Eastern Indonesia. IOP Conference Series: Earth and Environmental Science, IOP Publishing, 339(012026): pp. 2.

IUCN (2003). Guidelines for application of IUCN Red List Criteria at Regional Levels: Version 3.0. IUCN Species Survival Commission. IUCN, Gland, Switzerland.

IUCN (2012). IUCN Red List Categories and Criteria: Version 3.1. Second edition. Gland, Switzerland and Cambridge, UK.

IUCN (2020). The IUCN Red List of Threatened Species. Version 2020-2. https://www.iucnredlist.org.

Johnson SB, Waren A and Vrijenhoek RC (2008). DNA barcoding of Lepetodrilus limpets reveals cryptic species. Journal of Shellfish Research, 27(1): 43-51.

Kimura M. (1980). A simple method for estimating evolutionary rates of base substitutions through comparative studies of nucleotide sequences. Journal of Molecular Evolution, 16: 111-120.

Kumar R, Jaiswar AK, Pavan-Kumar AA, Chakraborty SK, Jahageerdar S and Lakra WS (2015). DNA barcoding of Thais species (Family: Muricidae) from west coast of India. Indian Journal of Fisheries, 62(2): 92-97.

Kumar S, Stecher G and Tamura K (2016). MEGA7: Molecular Evolutionary Genetics Analysis version 7.0 for bigger datasets. Molecular Biology and Evolution, 33(7): 1870-1874.

Marko PB and Moran AL (2009). Out of sight, out of mind: high cryptic diversity obscures the identities and histories of geminate species in the marine bivalve subgenus Acar. Journal of Biogeography, 36(10): 1861-1880.

Oostingh CH (1923). Recent shells from Java, Part I- Gastropoda, 26: 113.

Palomares MLD and Pauly D (2020). SeaLifeBase. World Wide Web electronic publication. www.sealifebase.org.

Perez KE, Defreitas N, Slapcinsky J, Minton RL, Anderson FE, and Pearce TA (2014). Molecular phylogeny, evolution of shell shape, and DNA barcoding in Polygyridae (Gastropoda: Pulmonata), an endemic North American clade of land snails. American Malacological Bulletin, 32(1): 1-31.

Philippi RA (1848). Testaceorum novorum centuria. Zeitschrift fur Malakozoologie, 5(2): 17-27.

Poutiers JM (1998). Gastropods. In: FAO Species Identification Guide for Fishery Purposes. Carpenter KE and Niem VH (Eds.). The Living Marine Resources of the Western Central Pacific, Rome, FAO, 1: 363-648. 
Rafinesque CS (1815). Analyse de la nature ou Tableau de l'univers et des corps organisés: 1-224.

Ramakrishna, Dey A, Barua S and Mukhopadhya A (2007). Fauna of Andhra Pradesh. Zoological Survey of India. State Fauna Series, 5 (Part-7), pp. 1-148.

Ran K, Li Q, Qi L, Li W and Kong L (2020). DNA barcoding for identification of marine gastropod species from Hainan island, China. Elsevier, 225: 105504.

Rao NVS, Dey A and Barua S (1992). Fauna of West Bengal, Part. 9 (Mollusca): Estuarine and Marine Molluscs. Records of the Zoological Survey of India, State Fauna Series 3: 129-268.

Saitou N and Nei M (1987). The neighbor-joining method-a new method for reconstructing phylogenetic trees. Molecular Biology and Evolution, 4(4): 406- 425.

Siddiqui KU, Islam MA, Kabir SMH, Ahmad ATA, Rahman AKA, Haque EU, Ahmed ZU, Begum ZNT, Hassan MA, Khondker M and Rahman MM (2007). Encyclopedia of Flora and Fauna of Bangladesh. Molluscs. Asiatic Society of Bangladesh, Dhaka, 17: 159-246.

Sun S, Li Q, Kong L, Yu H, Zheng X, Yu R, Dai L, Sun Y, Chen J, Liu J, Ni L, Feng Y, Yu Z, Zou S and Lin J (2016). DNA barcoding reveal patterns of species diversity among northwestern Pacific molluscs. Scientific Reports, 6(1): 33367.

Tan KS and Sigurdsson JB (1996). Two new species of Thais (Mollusca: Neogastropoda: Muricidae) from Peninsular Malaysia and Singapore, with Notes on T. tissoti (Petit 1852) and T. blanfordi (Melvill, 1893) from Bombay, India. The Raffles Bulletin of Zoology, 44 (1): 77-107.

Wahab MA, Shah MS, Hossain MAR, Barman BK and Hoq ME (2012). Advances in Fisheries Research in Bangladesh: I. Proceedings of the $5^{\text {th }}$ Biennial Fisheries Conference \& Research Fair 2012, Bangladesh Agricultural Research Council, Dhaka, Bangladesh Fisheries Research Forum, Dhaka, Bangladesh, pp.12.

Weigand AM, Jochum A, Pfenninger M, Steinke D and Klussmann-Kolb A (2011). A new approach to an old conundrum-DNA barcoding sheds new light on phenotypic plasticity and morphological stasis in microsnails (Gastropoda, Pulmonata, Carychiidae). Molecular Ecology Resources, 11(2): 255-265.

Weigt LA, Baldwin CC, Driskell A, Smith DG, Ormos A and Reyier EA (2012). Using DNA Barcoding to Assess Caribbean Reef Fish Biodiversity: Expanding Taxonomic and Geographic Coverage. PLoS ONE, 7(7): e41059.

Zou S, Li Q, Kong L, Yu H and Zheng X (2011). Comparing the usefulness of distance, monophyly and character-based DNA barcoding methods in species identification: a case study of Neogastropoda. PLoS ONE, 6(10): e26619. 